\title{
Fenntarthatósági célok - avagy tudjuk-e csökkenteni az alultápláltság mértékét?
}

\section{Sustainability Goals - Can we Reduce Malnutrition?}

\author{
D. FRÓNA
}

Debreceni Egyetem, Gazdaságtudományi Kar, Vidékfejlesztés, Regionális Gazdaságtan és Turizmusmenedzsment Intézet, frona.daniel@econ.unideb.hu

Absztrakt. A világ egyes részein az éhezés még mindig mindennapos jelenség. A millenniumi fejlesztési célok (MDGs) egyik sarkalatos pontja az éhség felszámolására. Ezek a célok tartalmazzák a haladás ütemtervét és az éhség leküzdésére irányuló konkrét lépések dokumentálását. Manapság az éhezés egy másik típusa, amely elötérbe került, a rejtett éhség. A szélsőséges szegénység és az éhség felszámolása még továbbra is csak illúzió. Az extrém szegénységben élők és az alultápláltságban szenvedók száma az utóbbi években enyhén csökkent. Az éhség mérése nagyon komplex dolog. A globális éhínség index (Global Hunger Index) egy olyan eszköz, amelynek célja az éhínség globális, regionális és nemzeti szintü átfogó mérése és nyomon követése. Az észrevehető javulások ellenére a kérdés továbbra is az, hogy 2030-ig a világ eléri-e a fenntartható fejlődési céljait (SDG), köztük az éhezés megszüntetését? Az eröfeszítések ellenére még a gazdaságilag fejlett országokban is felüti a fejét az éhezés vagy az élelmezésbizonytalanság.

Abstract. Nowadays, some parts of the world hunger still exists. One of the milestones of the Millennium Development Goals (MDGs) is eradicating hunger. These goals include a road map for progress and documenting specific steps to combat hunger. Another type of hunger that has been very common in these days is hidden hunger. Eradicating extreme poverty and hunger is still an illusion. The number of people living in extreme poverty and malnutrition has fallen slightly in recent years. Measuring hunger is a very complex issue. The Global Hunger Index is a tool to comprehensively measure and monitor hunger at global, regional and national levels. Despite noticeable improvements, the question remains: will the world achieve its Sustainable Development Goals (SDGs), including the eradication of hunger, by 2030? Despite these efforts, even in economically developed countries, hunger or food insecurity still exist.

\section{Bevezetés}

A globális népesség egy jelentős részének az éhezés vagy alultápláltság egy létállapot, napi állapot. $\mathrm{Az}$ éhség olyan akut állapot, amely során az egyén a kényelmetlenség érzéséből eljuthat az agresszív reakciókig, hogy a táplálékot bármilyen szükséges eszközzel megszerezhesse [1]. Evolúciós szempontból az élelmiszerek megszerzése közben az agresszívvá válás nélkülözhetetlen szabályozási mechanizmus, amelynek célja a faj megőrzése, fenntartása. A folyamatot számos biológiai aktivitás vezérli, amelyekben az anyagcsere és az agy számos komplex hormonja jelen van. Amint a történelem során is láthattuk, és a jövőben továbbra is látni fogjuk, az emberek „éhes tömegei” veszélyt jelentenek, mivel nem lehet kiszámítani vagy megjósolni az erőszakos cselekvések mértékét és intenzitását [1]. Napjainkban egyre inkább 
előtérbe kerül az éhezés egyik fajtája a rejtett éhség, a krónikus alultápláltság. Ez azért veszélyes, mert az ebben szenvedők nem mindig tudják, hogy érintettek, ezért a megelőzésre is kevés figyelmet fordítanak. A rejtett éhség, a krónikus alultápláltság egy olyan állapota, melynek következtében a legutóbbi energiaforrásait az egyén nem használta fel, hanem „tárolta”, túlzott kalória formájában [2]. A másik erre utaló állapot, amikor az egyén nem kalória, hanem úgynevezett mikrotápanyag (vitaminok, ásványi anyagok) hiányban szenved. Az energia megtakarítása azonban csak addig lehetséges, amíg a testnek megvannak a tartalékai (pl. kezdve a testben maradó kis zsírtartalommal, majd az izmokban lévő fehérjével) [2]. Miután ezek a tartalékok eltûntek, a test elkezdi metabolizálni azokat a raktárakat, amelyek elengedhetetlenek a testi funkciók ellátásához. Végül a test önmagát fogyasztja azzal, hogy megpróbálja kivonni a létfontosságú szervekben lévő fehérjét és energiát [3]. Ez a gyermekek növekedésében és fejlődésében rendellenességhez vezethet.

A téma megértéséhez elengedhetetlen az alábbi fogalmak tisztázása, melyhez a nemzetközi szakirodalmakon kívül a $F A O$ szójegyzékét használtam. Az angol definícióknak sokszor nincs magyar megfelelője, ezért egyes fogalmakat gyakran szinonim fogalomként kezelnek. A teljesség igénye nélkül a legfontosabb fogalmak:

- Élelmezés biztonság (food security): akkor létezik, amikor minden ember (társadalmi elhelyezkedéstől és anyagi háttértől függetlenül) fizikai hozzáféréssel rendelkezik elegendő mennyiségű és minőségű élelmiszerhez, amely kielégíti táplálkozási szükségleteiket és az élelmiszer-preferenciáikat. Az élelmiszerbiztonságnak négy dimenzióját vesszük alapul: a rendelkezésre állást, az ellátás stabilitását, hozzáférést és a felhasználást [4].

- Élelmezés-„,bizonytalanság” (food insecurity): Az élelmiszer-bizonytalanság akkor áll fenn, ha az emberek nem rendelkeznek megfelelő fizikai vagy gazdasági hozzáféréssel az előzőekben meghatározott élelmiszerekhez [4].

- Táplálkozásbiztonság (nutrition security): A táplálkozás biztonság akkor áll fenn, ha az élelmezésbiztonságot kombináljuk egy megfelelő egészségügyi környezettel és szolgáltatásokkal az egészséges élet biztosítása érdekében. A megfelelő higiénia, az egészség és a gondoskodás mellett a táplálkozási biztonság megköveteli olyan élelmiszerek fogyasztását is, amelyek megfelelően diverzifikáltak makro- és mikrotápanyagok tekintetében [4].

- Alultápláltság (undernourishment): Az alultápláltság olyan tápanyagbevitelt jelent, amely nem elegendő az egyén energiaigényének kielégítéséhez. Első számú idevezető ok a jövedelmek egyenlőtlen eloszlása, melynek következtében nem jut mindenki megfelelő mennyiségű és minőségű élelmiszerhez. Az alultápláltságot gyakran az „éhség” szinonimájaként tartják számon [4].

- Alultápláltság (mikrotápanyagokban) (undernutrition): akkor fordul elő, ha az elégtelen táplálékfelvétel következtében az egyén funkcionálisan hiányt szenved el vitaminok és / vagy ásványi anyagokból (mikrotápanyag alultápláltság) [4].

- Nem megfelelő táplálkozás (malnutrition): olyan széles kifejezés, amely a rossz táplálkozás minden formájára vonatkozik. Az alultápláltságot olyan összetett tényezők 
okozzák, mint a túlzott mértékű energia-, fehérje- és mikrotápanyaghiány. Az alultápláltság fogalma ebben az esetben magába foglalja a túlsúlyt és az elhízást is [4].

Az 1990-es években a millenniumi fejlesztési célok (MDGs) politikai válaszként jelentek meg a világ élelmezési problémáira. Ezek a célok magukban foglalják az előrehaladáshoz szükséges ütemtervet, valamint az éhezés elleni küzdelemben tett konkrét lépések dokumentálását [5]. A millenniumi fejlesztési célokat az Egyesült Nemzetek Szervezete (FAO) 55. közgyülése fogadta el 2000. szeptember 6-án. A legfőbb cél a szegénység 50\%-os csökkentése 2015-re. A kitűzött célokat nem tudták elérni, mivel

- jelenleg több mint 1 milliárd ember él a szélsőséges szegénységben (a világ lakosságának 20\%-a naponta kevesebb, mint 1 dollárból él),

- 700 millió ember alultáplált,

- 120 millió gyermeknek nincs esélye az oktatás megszerzésére,

- a világ lakosságának több mint 20\% -a nem fér hozzá a tiszta ivóvízhez [5].

A szélsőséges szegénység és az éhség felszámolása napjainkban még mindig csak illúzió. Mind a szélsőséges szegénységben élők, mind az alultápláltságban szenvedők száma csekély mértékben csökkent az elmúlt években. A Világbank (Worldbank) meghatározása szerint a „szélsőséges szegénység" napi 1,25 dollárnál kisebb jövedelemből megélő egyénnek felel meg, ami 1,4 milliárd ember esetében jelenleg is fennáll. További 2,6 milliárd ember 2 és 3 dollár között keres, ami nem elegendő a megfelelő táplálkozás biztosítására [6].

Az éhség mérése bonyolult. A globális éhínség index (Global Hunger Index) egy olyan eszköz, amelynek célja az éhínség globális, regionális és nemzeti szintű átfogó mérése és nyomon követése. A GHI pontszámokat minden évben kiszámítják az éhínség elleni küzdelemben elért előrehaladás függvényében. A GHI célja az éhínség elleni küzdelem tudatosítása és megértése, amely lehetővé teszi az éhínség szintjének összehasonlítását az országok és a régiók között, valamint felhívja a figyelmet a világ azon területeire, ahol az éhezés mértéke a legmagasabb[7]. De hogyan is mérjük a GHI értékét? A GHI pontszámokat az éhség többdimenziós jellegének megragadása érdekében különböző forrásokból származó adatokra támaszkodva számítják ki [2]. Először minden ország esetében az alábbiakat határozzák meg:

- alultápláltság: az alultáplált népesség aránya (azaz a kalóriabevitel elégtelen);

- gyermekkori nélkülözés: az öt éven aluli gyermekek tápanyag hiánya (magasság, súly, stb. visszamaradása);

- gyerek halandóság: az öt éven aluli gyermekek halálozási aránya (részben a nem megfelelő táplálkozás és az egészségtelen környezet végzetes keveréke) [5].

A mutatókra vonatkozó adatok az ENSZ és más ügynökségek adatgyüjtési erőfeszítéseiből származnak. Az alultápláltságra vonatkozó adatokat a $F A O$ nyújtja. A gyermekhalandósági adatokat az Egyesült Nemzetek gyermek halálozási adataival foglalkozó egysége (UN IGME) szolgáltatja. A gyermek eltűnés és a gyermekrablás adatait az UNICEF, az Egészségügyi Világszervezet $(W H O$ ) és a Világbank (Worldbank) közös adatbázisából, valamint a WHO folyamatosan frissített, a gyermeknövekedésről és az alultápláltságról szóló globális adatbázisból tudhatjuk meg. A Demográfiai és egészségügyi felmérések (DHS) és többszörös indikátor klaszterfelmérések (MICS) és statisztikai táblázatok az UNICEF-től származnak. 
A fenntartható fejlődés alapfogalma több mint három évtizede született meg. Az alapfogalom szerint a fenntartható fejlődés olyan fejlődés, amely kielégíti a jelen igényeit anélkül, hogy csökkentené a jövő generációk képességét saját igényeik kielégítésére [8]. Ennek az elvnek a végrehajtása különösen fontos a mezőgazdaságban, hiszen itt szűkösen rendelkezésre álló természeti erőforrásokat használnak fel. A mezőgazdaság környezetben, gazdaságban és társadalomban betöltött funkciói miatt komoly kihívások előtt áll. A megfigyelhető javulások ellenére továbbra is fennáll a kérdés, hogy a világ 2030-ig eléri-e a fenntartható fejlődés célját $(S D G)$, amelynek lényege az éhezés megszüntetése, az élelmiszerbiztonság és a jobb táplálkozás biztosítása, valamint a fenntartható mezőgazdaság előmozdítása. Azonban elmondható, hogy még mindig messze vagyunk az alultápláltság nélküli világtól [9]. Az éhezés és az alultápláltság nélküli világ 2030-ig való megvalósítása jelentős kihívást jelent, éppen ezért ennek elérése új erőfeszítéseket igényel, új munkamódszerek révén [10]. A gyermekek túléléséhez az SDG-célok elérése érdekében az országok több mint egynegyedében gyorsított előrelépés és cselekvési terv szükséges [11]. Az éhezés megszűntetése nem érhető el nagyobb erőfeszítések és új megközelítések használata nélkül. A GHI 2019 előrejelzései azt mutatják, hogy a 2000 óta eltelt éhínségcsökkenés ütemét figyelembe véve körülbelül 50 ország 2030-ig nem éri el az alacsony éhségszintet (GHI Severity Scale)[7]. A már elért pozitív eredményeket figyelembe véve azonban láthatjuk, hogy az előrelépés és a fejlődés lehetséges. Ennek ellenére a világ számos részén továbbra is a legnehezebb kihívást jelenti az SDG2 elérése, vagyis az éhínség és az alultápláltság mértékének csökkentése.

A GHI mutató és annak mögöttes mutatóértékei nemzeti és regionális szinten betekintést nyújtanak az értékek változásának miértjébe az idő múlásával (1. ábra). Regionális szinten a DélÁzsiában és Afrikában, a Szaharától délre fekvő GHI-pontszámok 2018-ban drasztikusan magasabbak, mint a világ más régióié [12]. Általánosan jellemzi az előbb említett területeket, hogy a gyermekek egészséges fejlődését negatívan befolyásoló tényezők közé tartozik a nem megfelelő élelmiszerek fokozott fogyasztása (magas cukor és finomított szénhidrát tartalmú ételek) , a megfelelő higiéniai hozzáférés hiánya, a nők oktatásának elmaradása, a biztonságos és fogyasztható vízhez való hozzáférés, a nemek közötti egyenlőtlenség és a nemzeti élelmiszerrendelkezésre állás [13]. A Szaharától délre fekvő afrikai részeken 2015-2017-es alultápláltsági ráta 22\%-kal emelkedett 2009-2011-es időszakhoz képest [14]. Az elhúzódó válsággal küzdő országok alultápláltsági aránya megközelítőleg kétszer olyan magas, mint a konfliktus által nem érintett országoké [15]. Az alultápláltságot kiváltó másik súlyos tényező az éghajlatváltozás kedvezőtlen hatásai. Egyre több országban tapasztalható az elsivatagosodás, melynek következménye a csökkenő terméshozam és például elsősorban ebből adódóan Afrikában az állatállomány csökkenése. Ezen körülmények tovább rontják a már amúgy is érzékeny helyzetet [16]. 


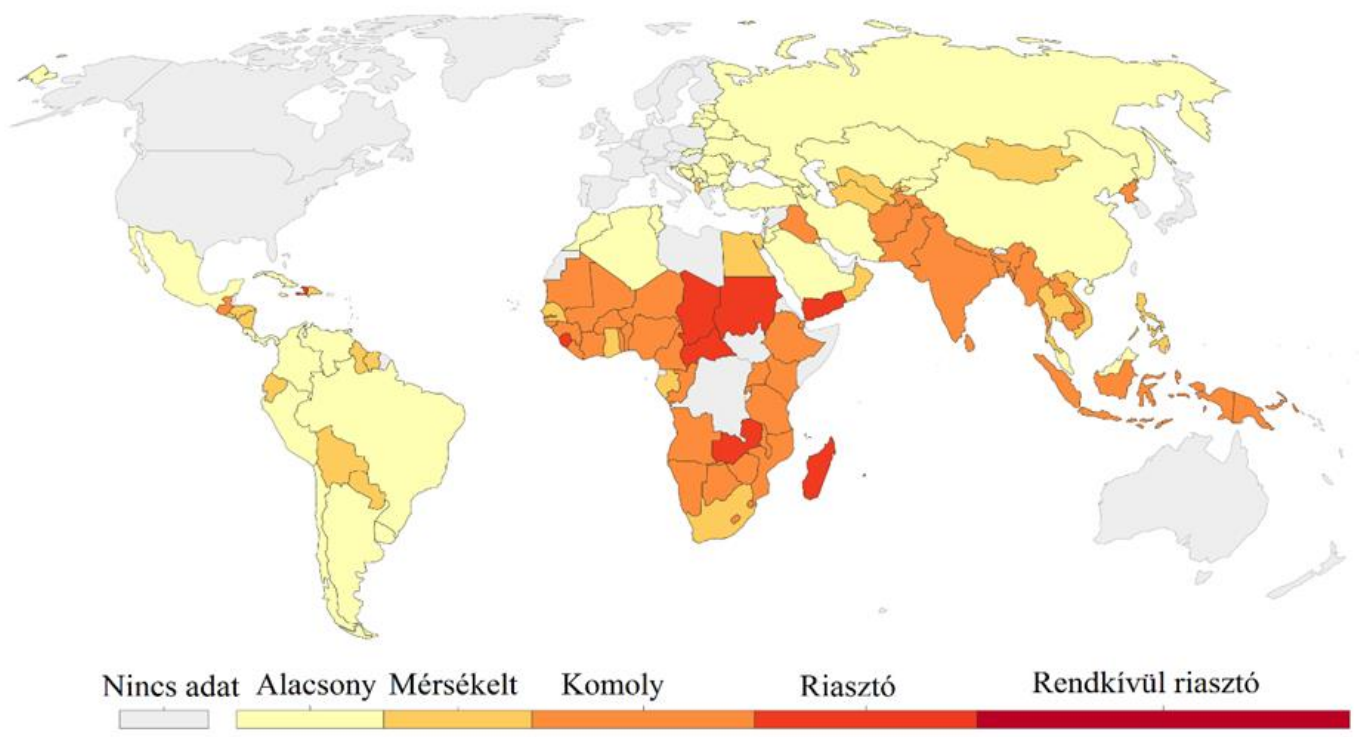

1. ábra. A globális éhségindex térképen ábrázolva, 2016

Forrás: International Food Policy Research Institute, 2018

Az élelmezésbiztonság instabilitása a rossz táplálkozás egyik fő forrása (ideértve az élelmiszerek elérhetetlenségét, megfizethetetlenségét vagy akár háztartások közötti egyenlőtlen eloszlását) [14].

A 2. ábrán az élelmiszer-ellátás bizonytalanságát láthatjuk 2014-2016 között, régiónkénti megoszlásban. Globális szinten mintegy 690 millió ember súlyos helyzetben van élelmezésbiztonság szempontjából. Afrikában a népesség közel harmada, Közép- és Dél-Ázsiában a népesség negyede; míg Európában és Észak-Amerikában a lakosság 2\%-a veszélyeztetett élelmiszerellátás tekintetében. Az utóbbi években (2014-től 2016-ig) a tendenciák Ázsiában és Afrikában jelentősen megváltoztak. Ázsiában a súlyosan élelmezésbizonytalanságok száma közel 30 millióval csökkent, míg Afrikában 40-45 millióval emelkedett az érintettek száma [17].

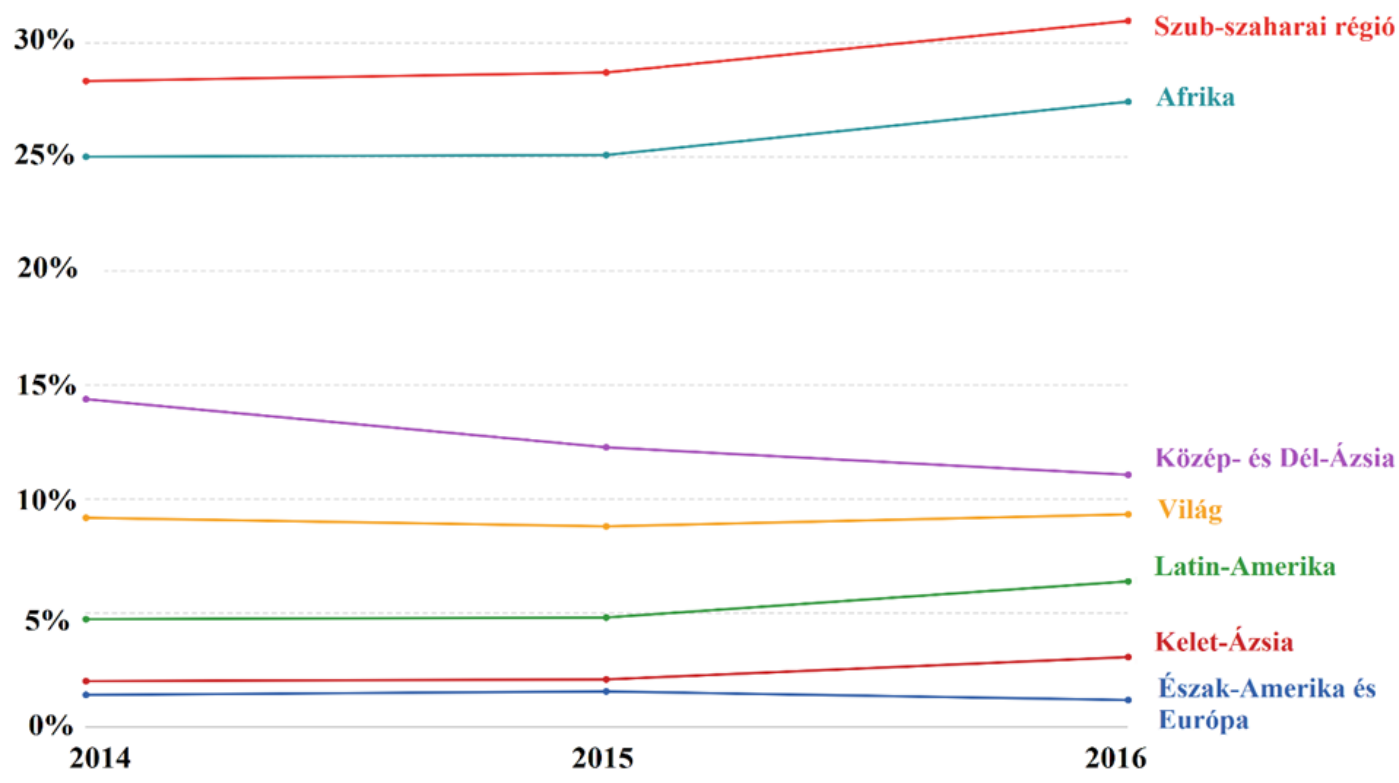

2. ábra. Az élelmezés ellátás bizonytalansága régiónként (2014-2016 között)

Forrás: Saját szerkesztés [9] alapján 


\section{Az alultápláltság}

A 3. ábra az alultápláltság gyakoriságát mutatja be a világ régióiban. Az ábrán azok tekinthetőek alultápláltnak, akiknek nincs megfelelő mennyiségű kalóriabevitele, ami fedezné az egyén létszükségletéhez nélkülözhetetlen minimális energiabevitelt. A diagram azokra a régiókra és országokra összpontosít, ahol a legnagyobb az alultáplált emberek aránya. A magas jövedelmü országok, a FAO és a Világbank meghatározása szerint, nem tartoznak a regionális becslésekbe, mivel a fejlett országokban az alultáplált emberek részaránya 2,5\% alatt lenne [17]. Ez például azt jelenti, hogy Japán nem szerepel a „Kelet-Ázsia” becslésében. Azokat az országokat, ahol az éhínség gyakorisága kisebb, mint 2,5\%, általában nem veszik figyelembe az értékelésekben és automatikusan 2,5\%-os értéket kapnak. Ezek az országok főként az európai kontinensen és Amerika északi részén helyezkednek el. Az alacsony számú éhezők arányát az ábrán a piros és a kék szín mutatja. A legveszélyezettebb régiók főként Dél-Ázsia és Afrika szaharai része, ahol az alultáplált emberek aránya meghaladja a 20\%-ot a teljes népességből [5].

Általánosságban elmondható, hogy a legtöbb régióban az éhezés gyakorisága az ezredforduló óta csökkent. Globális szinten ez a 2000. évi 14,8\%-ról 2016-ban 10,8\%-ra esett vissza. Ez a pozitív tendencia az elmúlt három évben alább hagyott. A globális éhínség 2015-ben 10,6\%-on érte el a legalacsonyabb szintet, majd 2016-ban 10,8-ra emelkedett [10]. Az éhségszintek növekedése nagyrészt a Szaharától délre eső afrikai részen bekövetkezett éhezők számának növekedésnek (ahol az arány az utóbbi években több százalékponttal emelkedett), valamint a Közel-Kelet és Észak-Afrika kismértékű emelkedésének tudható be. Elmondható, hogy szoros korreláció van az alultápláltság növekedése és az éghajlattal kapcsolatos negatív tényezők között is [5].
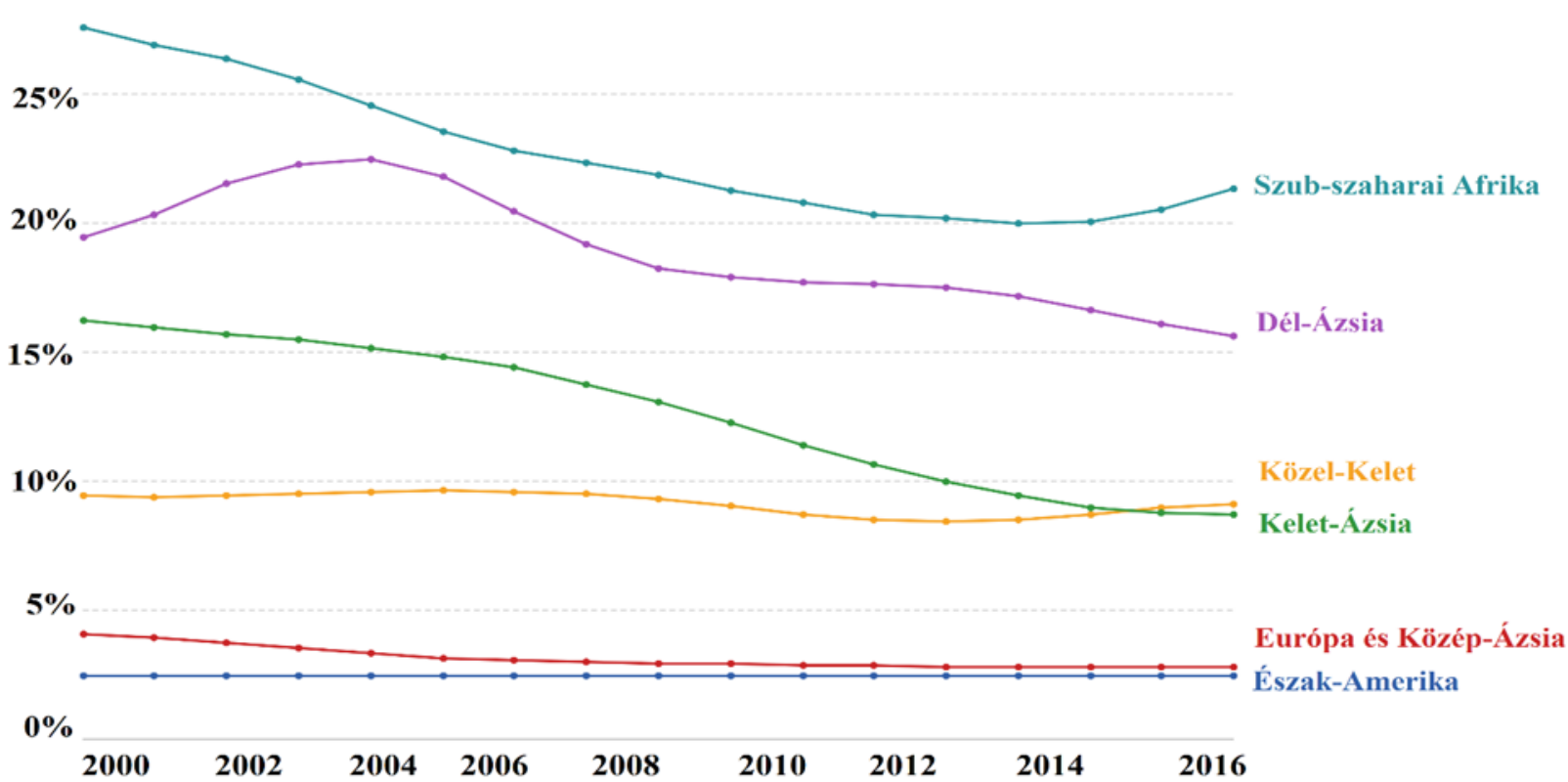

3. ábra. Az alultáplált népesség megoszlása régiónként, 2000 és 2016 között

Forrás: Saját szerkesztés [6] és [4] alapján

A 4. ábrán az alultápláltság és az extrém szegénységben élő gyerekek közötti kapcsolatot lehet megfigyelni. Az alultápláltság vagy az életkor szerint túlsúlyosság előfordulása főként azokat a gyerekeket veszi figyelembe, akik hosszabb ideig nem jutottak megfelelő táplálékhoz, nélkülöztek 
vagy szenvednek az elégtelen energiabevitel miatt. Azok az 5 évnél fiatalabb gyerek számítanak alultápláltnak az ábrán, akiknek a súlya nem éri el a nemzetközi referencia korabeli populációjának mediánját. A szélsőséges szegénységet úgy lehet meghatározni, mint aki kevesebb, mint 1,9 dollárból él naponta (az inflációval és az országközi árkülönbségekkel kiigazítva) [17].

Az ábra alapján elmondható, hogy folyamatosan csökken a globális alultápláltság szintje: az 1990es mintegy 25\%-ról 2015-re 15\%-ra esett vissza. Dél-Ázsia - annak ellenére, hogy a legmagasabb értékkel bír a régióban (16\% körüli alultápláltsági ráta) jelentős előrelépést tett az utóbbi évtizedekben, 1990 és 2017 között 20 százalékponttal csökkentett az alultápláltság mértéke. Az alultápláltság szintje szintén jelentősen csökkent a szub-szaharai Afrikában, az 1990-es 30\%-ról a 2017-es 20\% -ra csökkent [17].

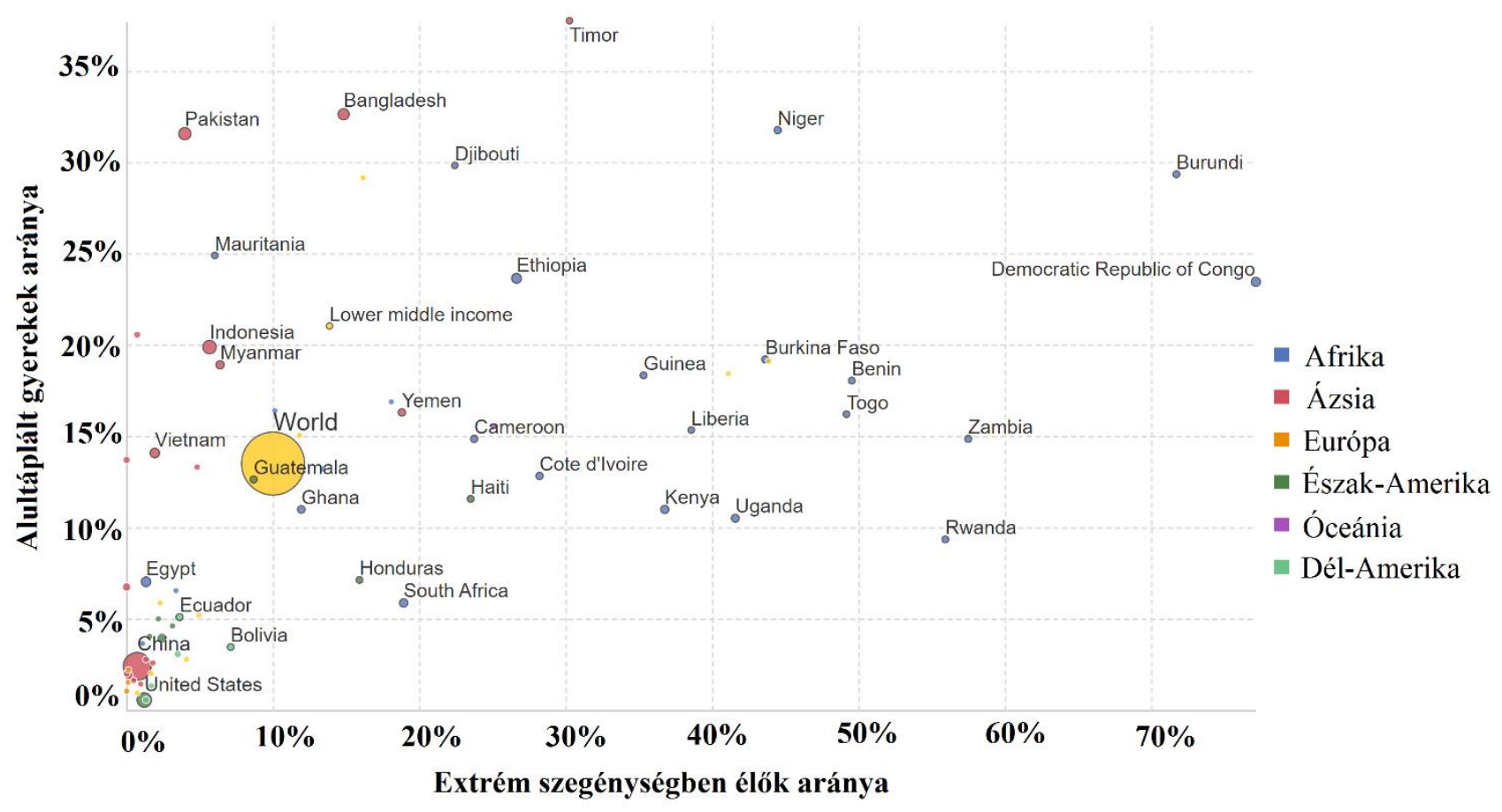

4. ábra: Kapcsolat az alultápláltság és az extrém szegénység között a gyerekek körében, 2017

Forrás: Saját szerkesztés [16]

A 4. ábra megjeleníti az alultápláltság meglétét a gyereknél és az extrém szegénység közötti kapcsolatot. Az ábrán a régiók különböző színekkel vannak jelölve, az országokat jelölő pontok nagysága pedig az adott ország népességének nagyságától függ. Megfigyelhető, hogy ahol a létminimum alatt élők aránya nagyobb a teljes népességhez viszonyítva, ott az alultáplált gyermekek aránya is magasabb. A legveszélyeztetettebb területek egyes ázsiai és afrikai régikra koncentrálódnak. Kiugró értéket képvisel például a Kongói Demokratikus Köztársaság, ahol 70\% feletti az extrém szegénységben élők aránya és 25\% körüli az alultáplált gyerekek aránya is. Ellenpélda például az Amerikai Egyesült Államok, ahol mindkét mutató 1\% körül mozog.

\section{Összegzés}

Közel 20 év alatt, az éhezés és az alultápláltság csökkentése terén tett globális intézkedés haladást mutat, de a problémát még koránt sem sikerült véglegesen felszámolni. A jövőre vonatkozó fontos 
kérdés, hogy vajon a világ képes-e továbbra is haladást elérni e betegségek megszűntetése érdekében? A nemzetközi és kormányzati szinten történő célzott intézkedések eredményeként az emberi jólétet és egyenlőség javuló tendenciát mutat. Ugyanakkor a javulás mellett számos aggodalmat keltő ok is megtalálható. Az intézkedések ellenére az alultáplált emberek száma bizonyos régiókban növekszik. A szélsőséges időjárási események veszélyeztetik az élelmiszerelőállítást és az élelmezésbiztonságot. Várhatóan a globális éghajlatváltozással összefüggő káros események száma és súlya tovább fog nőni. A természeti erőkön túl sok ország szenved erőszakos bel- és külpolitikai konfliktusoktól, melyek - a számos borzalom mellett - jelentősen növelik az éhezők számát. Egyenlőtlenségek a gyermekek táplálkozásában szubnacionális szinten és a folyamatos élelmezésbiztonság megléte ellenére a magas jövedelmű országokban is előfordul. Még a virágzó gazdaságokban is figyelemmel kell kísérni az élelmezésbiztonság helyzetét és támogatást kell nyújtani azon társadalmi réteg számára, akik nehézséggel küzdenek. Minderre azért is szükség van, mert az éhezés és az alapvető életfeltételek bizonytalansága hatására migrációs hullám is indulhat, ami a világ fejlettebb országai irányába vezetheti a nélkülözés által sújtott területeken élőket [17], ahol újabb kihívásokkal szembesülhetnek a mai nélkülözők [18; 19].

\section{Köszönetnyilvánítás}

„Az Innovációs és Technológiai Minisztérium ÚNKP-19-3-I-DE-387 kódszámú Új Nemzeti Kiválóság Programjának szakmai támogatásával készült.”

Debreceni Egyetem, Ihrig Károly Gazdálkodás- és Szervezéstudományok Doktori Iskola.

\section{Hivatkozások}

[1] Gödecke T, Stein AJ, Qaim M: The global burden of chronic and hidden hunger: Trends and determinants. Global food security 2018, 17:21-9.

[2] Ruel-Bergeron JC, Stevens GA, Sugimoto JD, Roos FF, Ezzati M, Black RE, Kraemer K: Global update and trends of hidden hunger, 1995-2011: the hidden hunger index. PLoS One 2015, 10:e0143497.

[3] Meena PC, Meena PC, Choudhary A: Biofortification of cereal crops: An emerging strategy to overcome hidden Hunger. IJCS 2018, 6:776-85.

[4] FAO: Glossary of terms. 2019.

[5] Klaus von Grebmer JB, Fraser Patterson, Andrea Sonntag, Lisa Maria Klaus, Jan Fahlbusch, Olive Towey,, Connell Foley SG, Kierstin Ekstrom, and Heidi Fritschel: Global hunger index. Dublin / Bonn, 2018.

[6] WorldBank: Data Indicators. 2018.

[7] Klaus von Grebmer JB, Fraser Patterson, Miriam Wiemers, Réiseal Ní Chéilleachair, Connell Foley, Seth Gitter, Kierstin Ekstrom, and Heidi Fritschel GLOBAL HUNGER INDEXTHE CHALLENGE OF HUNGER AND CLIMATE CHANGE. Dublin / Bonn, 2019. 
International Journal of Engineering and Management Sciences (IJEMS) Vol. 5. (2020). No. 1

DOI: $10.21791 /$ IJEMS.2020.1.23

[8] Auty RM, Mikesell RF: Sustainable development in mineral economies: Clarendon Press, 1998.

[9] Unicef: Levels and trends in child malnutrition. eSocialSciences, 2018.

[10] FAO: The state of Food Security \& Nutrition around the World 2018.

[11] Hug L, Alexander M, You D, Alkema L, for Child UI-aG: National, regional, and global levels and trends in neonatal mortality between 1990 and 2017, with scenario-based projections to 2030: a systematic analysis. The Lancet Global Health 2019, 7:e710-e20.

[12] De Onis M, Borghi E, Arimond M, Webb P, Croft T, Saha K, De-Regil LM, Thuita F, Heidkamp $\mathrm{R}$, Krasevec J: Prevalence thresholds for wasting, overweight and stunting in children under 5 years. Public health nutrition 2019, 22:175-9.

[13] Smith LC, Haddad L: Reducing child undernutrition: past drivers and priorities for the post-MDG era. World Dev 2015, 68:180-204.

[14] FAO: Food Security Indicators. 2018.

[15] WHO: The State of Food Security and Nutrition in the World 2018: Building climate resilience for food security and nutrition: Food \& Agriculture Org., 2018.

[16] Fellmann T, Witzke P, Weiss F, Van Doorslaer B, Drabik D, Huck I, Salputra G, Jansson T, Leip A: Major challenges of integrating agriculture into climate change mitigation policy frameworks. Mitigation and Adaptation Strategies for Global Change 2018, 23:451-68.

[17] OURWORLDINDATA: Hunger and Undernourishment. 2019. 